Article

\title{
Investigating Predictors of Public- and Private-Sphere Sustainable Behaviors in the Context of Agritourism
}

\author{
Sara Brune *(D), Whitney Knollenberg *(D), Kathryn Stevenson (D) and Carla Barbieri \\ Department of Parks, Recreation and Tourism Management, North Carolina State University, \\ Raleigh, NC 27695, USA; kathryn_stevenson@ncsu.edu (K.S.); carla_barbieri@ncsu.edu (C.B.) \\ * Correspondence: sbrunea@ncsu.edu (S.B.); whitney_knollenberg@ncsu.edu (W.K.)
}

\begin{abstract}
Encouraging sustainable behaviors regarding food choices among the public is crucial to ensure food systems' sustainability. We expand the understanding of sustainable behavioral change by assessing engagement in local food systems (LFSs) in the context of agritourism experiences. Using theory of planned behavior (TPB) and personal norms, we conducted pre-post-surveys at agritourism farms to measure the impact of changes in the TPB behavioral antecedents as predictors of the following behavioral intentions regarding LFS engagement: (1) purchasing local food (privatesphere behavior), (2) increasing monthly budget to purchase local food (private-sphere behavior) and (3) advocating for local food (public-sphere behavior). Our findings indicate that strategies to encourage LFS engagement should seek to activate moral considerations that can motivate action across private and public behaviors, which applies to various demographic groups. To stimulate collective action, strategies should target subjective norms specifically (e.g., encouraging social interaction around local food), while strategies encouraging private behaviors should focus on easing perceived barriers to buying local food (e.g., promoting local food outlets). As agritourism experiences effectively modify the three above-mentioned behavioral antecedents, we advocate for holistic experiences that provide opportunities for deeper engagement with local food, stimulate the senses, and facilitate social interaction around LFSs.
\end{abstract}

Keywords: holistic experiences; local food systems; personal norms; theory of planned behavior

\section{Introduction}

The publication of the Brundtland Commission Report, Our Common Future [1], instigated considerable debate about the need to change the world's economic, social and environmental systems to strive for sustainability. Over three decades later, deterioration of ecosystems, social marginalization, and wealth condensation continue to represent substantial challenges that require increased public participation in sustainable behaviors [2-5]. One category of sustainable behaviors that may be particularly impactful to overall global sustainability are those related to food choices $[4,6]$. Food systems are a sizable part of the world economy, employing 1 billion people [7]. Yet, one in four people are food insecure around the globe [8], and therefore achieving food security and promoting sustainable agriculture is one of the top priorities of the Sustainable Development Goals [9]. Food systems greatly contribute to climate change by generating approximately $30 \%$ of greenhouse gas emissions [10,11], accounting for $70 \%$ of water use [12], and occupying $36 \%$ of ice-free land [13]. Thus, encouraging the public to make informed food choices through their purchasing and voting behaviors could have a major positive effect on the sustainability of food systems [14], and individual behaviors can greatly reduce environmental degradation and contribute to achieving sustainability objectives [15].

The negative impacts of food systems are partly related to their increasing globalization. This leads to escalating "food miles," that is, the distance food travels from the production's regions to the consumers' home and the associated need for packaging, processing, and storing among global consumers [16]. Globalization of food systems also 
produces high levels of waste and threatens biodiversity and animal welfare, while excluding rural communities from economic gains $[5,17]$. Increasing the public's engagement in local food systems (LFSs) can decrease the reliance on globalized food systems, mitigate environmental impacts, and ameliorate the social and economic negative impacts of food systems $[18,19]$. Public engagement in LFSs (e.g., purchasing local food and advocating for policies supporting LFSs) is considered a sustainable behavior [20] because it tends to incorporate family farms that are more resilient to climate change, may adopt environmentally sustainable practices more easily, and may increase the food sovereignty of a region [21,22]. Yet, in the United States of America (USA), public engagement in LFSs is limited [23], which calls for increasing knowledge to encourage such engagement [18].

\subsection{Strategies to Promote Sustainable Behaviors}

Efforts to encourage sustainable behaviors most often include structural and informational strategies [24]. Structural strategies aim to change the decision-making context, such as shortening the distance to access local produce [25]. Informational strategies seek to change individuals' psychosocial factors such as affect, cognitions, and norms by providing information about positive or negative consequences of performing a behavior [26]. Common informational strategies regarding sustainable behaviors related to LFS engagement include the use of labels [27,28], slogans [29,30], and websites [31]. Yet, these communication strategies have had a limited positive impact [27,29] due to lack of trust [32], convenience [33], and difficulties targeting audiences and ensuring consumers understand the message [34].

Experiential strategies, which have been long studied in the fields of environmental education and outdoor recreation [35-37] and nature-based tourism experiences [38-41], are a third way to encourage sustainable behaviors. Experiential strategies provide more than information to participants by engaging their five senses to evoke an attitudinal response [42]. Nature-based experiences effectively promote positive attitudinal and behavioral changes when compared to other educational efforts, such as classroom lessons that only lead to knowledge gain $[43,44]$. In the interpretation field, holistic experiences in nature are considered some of the most successful interventions to achieve behavioral changes [26]. The term holistic experiences refer to providing a compelling picture through a place-based story that is relevant to participants, as well as clear take-home activity for participants to reflect upon after the experience [45].

Agritourism - recreational or educational activities conducted on a working farm [46] is not typically categorized as a nature-based experience. Yet, it embodies many of the same attributes of holistic experiences because it "incorporates principles of experiential and place-based education" [46] (p. 2334), thus making it well suited for encouraging sustainable behaviors. Agritourism experiences offer immersive engagement with agricultural landscapes through hands-on activities and a highly sensory experience that allows visitors to engage with the smells and sounds of nature and agriculture [47,48]. Agritourism experiences frequently entail on-site experiential food consumption, promoting a connection with the local context [49] and highlighting the benefits of local food [47,48,50]. Additionally, agritourism operators conserve environmental and cultural resources to offer authentic settings, prompting family interactions and producing memorable experiences [51]. Brune et al. (2021) found that agritourism experiences increase intentions to perform sustainable behaviors (e.g., buy local food) and the behavioral antecedents (attitudes, subjective norms, perceived behavioral control) driving those sustainable behaviors [52]. Collectively, these attributes substantiate that agritourism is a holistic experience and a suitable setting to study sustainable behavioral change $[18,19]$.

How and why holistic experiences influence sustainable behaviors is speculated upon through circumstantial evidence [26]. Although the effectiveness of holistic experiences to achieve educational objectives is well established, the mechanism through which experiences influence sustainable behavior and the role that modifying behavioral antecedents play in behavioral change is still not fully developed $[38,53,54]$. Two dominant approaches 
are used in studies of behavioral antecedents. The first approach presents a snapshot of how behavioral antecedents influence behaviors at a fixed moment in time [55-57]. This approach does not account for how behavioral antecedents are continuously being influenced by, for example, regular engagement in food-related experiences such as agritourism [49], or structural aspects (e.g., easily accessible farmers market) [58]. A second approach focuses on measuring changes in behavioral antecedents and sustainable behaviors after an intervention $[59,60]$. Although this approach is vital to understanding intervention effectiveness, it does not provide insight into the process through which behavioral change occurs [54]. Thus, both approaches, although important, provide a limited understanding of how changes in behavioral antecedents may influence behavior.

To fill the aforementioned gap, we propose to analyze the impact of modifying behavioral antecedents while accounting for different types of behavioral intentions. First, measuring whether changes in behavioral antecedents (e.g., attitudes and norms) as a result of a holistic experience predict changes in behavioral intentions which can lead to assessing behavioral antecedents in action. This is in line with a shift from regarding attitudes and behavior solely as outcomes of experiences to observing them as part of a transformation process [39]. Second, examining whether changes in behavioral antecedents have a differentiated impact depending on the type of behavior being targeted can help encipher differences and similarities between private- and public-sphere behaviors [20,61,62]. Private-sphere behaviors refer to purchasing, using, and disposing of products at the household level, while public-sphere behaviors refer to advocacy or environmental activism to influence policies or civic action [63]. Considerable attention has been placed on private behaviors (e.g., waste management and transportation) with public-sphere behaviors (e.g., supporting pro-environmental policies) receiving less attention $[54,64]$. Such attention disparity should be reduced considering the societal benefits (e.g., environmental quality improvement) that public-sphere behaviors can provide [6]. Furthermore, providing a comparative analysis of the impact of modifying behavioral antecedents private versus public behaviors could advance the formulation of effective policies and interventions for improving a range of public's sustainable behaviors.

In summary, a promising approach to understanding how holistic experiences alter sustainable behaviors entails assessing how changes in behavioral antecedents influence changes in different types of behavioral intentions (private versus public sphere) within the context of a specific intervention (agritourism experiences in this case). Advancing the understanding of the relative importance of modifying TPB behavioral antecedents on private- versus public-sphere behaviors in the context of experiential interventions could advance theory and practice by revealing how to better target intervention strategies to promote sustainable behaviors. In the case of agritourism, such information can help operators to design actions to engender sustainable behaviors among visitors. Thus, we investigated whether changes in the TPB behavioral antecedents resulting from agritourism experiences influence three types of sustainable behavioral intentions regarding LFS engagement: (1) purchasing local food (private-sphere behavior), (2) increasing monthly budget to purchase local food (private-sphere behavior), and (3) advocating for local food (public-sphere behavior). To understand how changes in behavioral antecedents influence changes in sustainable behaviors, it is necessary to understand the knowledge so far in terms of behavioral antecedents.

\subsection{Past Research}

Broadly, sociodemographic characteristics (e.g., age, sex, race/ethnicity, and socioeconomic status) and psychosocial factors such as motivations, attitudes, knowledge, values, and norms are behavioral antecedents $[65,66]$. Yet, psychosocial factors are better predictors of sustainable behaviors compared to demographic characteristics or the context [54]. Attitudes represent a summary evaluation of the behavior in terms of its positive or negative attributes [67]. The extant literature showed conflicting conclusions on the effect of attitudes on behaviors. One set of studies conclude that attitudinal aspects are good 
predictors of behavioral intentions both in private and public spheres $[20,68,69]$, specifically related to food consumption, general pro-environmental personal practices, sustainable food consumption, and green behaviors while on vacations [20,54,70-74]. These findings have informed the design of interventions to promote sustainable behaviors usually seeking to modify their antecedent attitudes [75]. Conversely, another set of studies refer to the attitude-behavior gap as they concluded that attitudes are not good predictors of sustainable behaviors $[66,76,77]$. Additionally, attitudes may affect certain types of behavior only when they are aligned with subjective norms and perceived behavioral control, or when there are no direct impediments to the behavior, indicating that external factors may constraint the behavioral expression of attitudes [63,71]. These inconsistent findings merit more research to understand under which circumstances attitudes influence sustainable behaviors [71].

Perceived behavioral control denotes perceived barriers or perceptions about how easy or difficult it is to perform a behavior [78]. Consistently, studies have established a significant positive effect of perceived behavioral control on intention to participate in sustainable behaviors [71-73], serving as a mediator of attitudes and subjective norms [71]. Additionally, Klöckner (2013) found that the influence of perceived behavioral control on intentions has a temporal dimension; its influence is greater at the beginning but it fades as a habit is established with repeated behavior [79]. When it comes to the effect on private versus public behavior, perceived behavioral control predicts sustainable behaviors if performed privately (e.g., recycling) but does not predict public-sphere behaviors [20,69], most likely because public-sphere behavior is independent of perceived barriers when citizens feel helpless and activism is perceived as a last recourse to address the problem [20].

Subjective norms entail an individual's beliefs about whether significant othersfamily or friends-think he or she should perform a behavior [78]. Subjective (or social) norms are an antecedent that more consistently predicts participation in sustainable behaviors as people tend to mimic their significant others' actions [80] or participate in those behaviors when significant others expect them to engage in them [72]. This social pressure can affect participation in sustainable behaviors [81], even if personal attitudes towards those behaviors are negative [73]. Yet, some studies found that subjective norms had either no effect [71] or an indirect effect on sustainable behavioral intentions [79]. This is especially true related to private-sphere behaviors, which might be associated with the limited opportunities people have to directly observe others engaging in sustainable behaviors [69]. Thus, further research conducted in diverse social contexts and for different behaviors is needed to better determine the impact of subjective norms on sustainable behaviors [80].

Personal norms - or feelings of moral obligation—are self-imposed expectations about performing an action [82]. Personal norms are activated in individuals "who believe their behaviors pose threats to other people, other species, or the biosphere" [83] (p. 85). Since sustainable behaviors may require a commitment to overcome barriers, activating personal norms may motivate the public to engage in sustainable behaviors. Personal norms were found to be a strong predictor of public-sphere behaviors, specifically on environmental policy support [64,84], and of private-sphere behaviors, specifically related to recycling, energy use, and food and transportation choices [54,84]. Several authors also suggest personal norms are a good addition to the TPB [85-87], having been found to be the strongest determinant of environmental complaint intention [88]. Nonetheless, more research is required to determine the usefulness of expanding TPB with personal norms across different behaviors [86].

\subsection{Current Study}

We expand the understanding of sustainable behavioral change by assessing LFS engagement in the context of agritourism experiences. We observed the differentiated impact of changes in TPB behavioral antecedents on private versus public behavior, broadening the understanding of sustainable behaviors [18,74]. We use TPB to build on the various studies that use this approach in both sustainable $[56,69,72,85]$ and food-related 
behaviors $[70,87,89]$. To do so, we measured three interrelated LFSs behavioral intentions as follows. First, we measured intentions to purchase local food (private-sphere behavior) as it contributes to the economic viability of LFSs by increasing local food demand [90]. Second, we measured the likelihood of increasing household budget to buy local food (private-sphere behavior) as family farms may encounter challenges when competing with the low prices industrial food systems offer [90]. Third, we measured intentions to advocate for local food or encourage others to support local food (public-sphere behavior) as local food advocacy is necessary to amplify the impact of interventions to strengthen LFSs [18].

Although there is extensive information on the impact of experiences on knowledge, attitudes, and concern, how the changes in these behavioral antecedents influence sustainable behaviors needs more research [26]. Thus, our first research objective is to determine how changes in the behavioral antecedents attitudes, subjective norms, perceived behavioral control, and personal norms impact the three pro-environmental behavioral intentions. More research is also needed to understand how these antecedents may operate differently when considering different types of behaviors. Accordingly, our second research objective is to compare how changes in behavioral antecedents resulting from an agritourism experience may influence public- versus private-sphere behaviors.

\section{Materials and Methods}

\subsection{Study Setting and Sample}

This study is part of a larger research project that required that sampled farms offered: educational activities such as a guided tour; hands-on agricultural activities such as Upick; offerings for children (e.g., playground); and an on-farm shop. The North Carolina Department of Agriculture and Consumer Services provided a list of 43 agritourism farms located across North Carolina (NC, USA) that fulfilled these criteria. Of these farms, we selected ten potential farms offering similar programming capabilities (e.g., number of visitors per year; parking availability; open during weekends) to collect data. We aimed to sample at least one farm per each of the three regions in North Carolina during the two peak agritourism seasons. We provided four farms with an explanation of data collection procedures and three farms agreed to participate in this study during the fall season (Upick apples and pumpkins). Given the low number of surveys achieved in the piedmont region during the fall season, for the spring season, we prioritized two farms located in the piedmont region and one in the east to increase the numbers in those regions for the spring season (U-pick strawberries) for a total of six farms (Table 1). Thus, one farm was in the west, three farms in the piedmont, and two farms in the eastern region of NC.

Table 1. Number of surveys per farm.

\begin{tabular}{cccc}
\hline Season & Region & Farm & n \\
\hline \multirow{2}{*}{ Fall } & East & Farm 1 & 72 \\
& West & Farm 2 & 85 \\
& Piedmont & Farm 3 & 16 \\
\multirow{2}{*}{ Spring } & East & Farm 4 & 52 \\
& Piedmont & Farm 5 & 87 \\
& Piedmont & Farm 6 & 16 \\
\hline
\end{tabular}

This study is a component of a larger project researching the impact of agritourism experiences on families. This informed our respondent selection criteria, which were families visiting any of the chosen agritourism farms that included one adult accompanied by at least one child between the ages of 9 and 13 years old. We aimed for a minimum sample size of 110 (10 observations per parameter) [91]. We only include the adults' data in this paper. 


\subsection{Measures}

We developed a survey instrument guided by the TPB constructs and personal norms to measure the impact of agritourism experiences on the behavioral antecedents and behavioral intentions regarding LFS engagement. We sought to obtain a minimum of three items per construct as the minimum number of items necessary to represent a latent factor [92]. TPB emphasizes that attitudes towards the behavior (e.g., attitudes towards advocating for local food) determine intentions. Yet, the literature on local food indicates that attitudes towards the attributes of local food (e.g., local food tastes good) influence LFS engagement [93]. Thus, we measured two types of attitudes: attitudes towards the behavior and attitudes towards local food. We drew upon previously developed scales from the literature for these constructs and utilized five-point Likert scales $(1=$ strongly disagree, 5 = strongly agree): (1) Attitudes towards purchasing local food (4 items, e.g., "when I purchase local food I am doing something good for the environment") [94]; (2) attitudes towards the attributes of local food (3 items, e.g., "local food is fresh") [95]; (3) subjective norms (4 items, e.g., "people who are important to me think I should purchase local food") [96,97]; (4) perceived behavioral control (7 items, e.g., "if I wanted to purchase local food I do not have to travel too far to get them" [96,97] (Please see Appendix A for individual survey items).

We included three behavioral intentions regarding LFS engagement: (1) local food purchasing - private-sphere behavior, (2) likelihood to increase budget to purchase local food-private-sphere behavior, and (3) likelihood to advocate for local food-public-sphere behavior. We measured intentions to engage in these behaviors on five-point Likert scales ( 1 = very unlikely, $5=$ very likely) as follows: participants' likelihood to purchase local food: six items, e.g., "how likely are you to purchase at a farmers' market?" [98]; intentions to increase monthly budget to purchase local food: three items, e.g., "how likely are you to increase your monthly budget by $10 \%$ to purchase local food?" [96]; advocacy for local food: four items, e.g., "how likely are you to speak with your elected representatives about supporting local food?" [98,99].

We collected the following sociodemographic characteristics: sex (female, male, and other), age (continuous variable), level of formal education (categorical ranging from high school degree or less to a graduate degree), race and ethnicity (eight categories), and annual household income (categorical ranging from $\$ 25,000$ or less to $\$ 200,000$ or more).

\subsection{Data Collection and Analysis Procedures}

To assess the impact of an agritourism experience on the behavioral antecedents and on intentions to participate in sustainable behaviors we employed a pre-post design in which surveys were administered before and immediately after the respondents engaged in agritourism experiences. We intercepted families fulfilling the participant criteria as they entered the farm and introduced them to the study objectives, requirements (completion of the pre- and post-surveys), and incentive (a five-dollar voucher for the on-farm market). If the adult agreed to participate, they signed a consent form. After concluding the presurvey, we asked participants to wear a sticker so they could be identified at the end of their visit to complete the post-survey. The pre- and post-surveys contained the same questions, though we only collected sociodemographic characteristics in the pre-survey. The surveys were self-administered through electronic (iPads using the Qualtrics offline application). Participants provided an identifier composed of their initials and birth date so pre-survey and post-survey responses could be matched. The pre-post design allowed us to establish a baseline and control for agritourists with differing local food interests, attitudes, and behaviors.

In preparation for the analysis, we first assessed the internal reliability and ensure acceptable multicollinearity of the survey instrument scales. Following recommended thresholds, we ensured that the Cronbach's alpha $(\alpha)$ was greater than 0.6 [100] and variance inflation factor (VIF) lower than five, respectively [101]. We then summed individual scale items within each construct to generate an index and subtracted the pre-tests scores 
from their post-tests scores to obtain the pre- and post-differences in each construct [102]. Next, we ran three separate linear regressions to estimate the effect of the changes in the TPB behavioral antecedents and personal norms on intentions to purchase local food, intentions to increase monthly budget, and intentions to advocate for local food $(p<0.05)$. We controlled for sociodemographic characteristics (i.e., age, sex, race, education, and income) and a ceiling effect by including the pre-test score of each behavioral intention, respectively [103].

\section{Results}

We obtained 328 pre-post-matched surveys. Most respondents were between 30 and 49 years old $(83.8 \%)$, female $(76.8 \%)$, held a college degree $(60.9 \%)$, and earned a household income above $\$ 75,000$ before taxes (57.9\%). Respondents were predominantly white $(80.8 \%)$ followed by Hispanic $(6.1 \%)$, Asian $(4.6 \%)$, and Black $(4.3 \%)$. Table 2 presents the demographic variables included in the analysis.

Table 2. Demographic variables.

\begin{tabular}{cccccc}
\hline Variable & $n$ & Mean & Std. Dev. & Min & Max \\
\hline Age & 321 & 39.586 & 7.824 & 21 & 74 \\
Male & 327 & 0.232 & 0.423 & 0 & 1 \\
Non-white & 328 & 0.192 & 0.395 & 0 & 1 \\
College education & 325 & 0.609 & 0.489 & 0 & 1 \\
Annual income above \$75,000 & 318 & 0.579 & 0.495 & 0 & 1 \\
\hline
\end{tabular}

Note: The sample size differs for each variable due to non-response.

Reliability analysis for the scales demonstrated adequate internal reliability $(\alpha \geq 0.713)$. We found a low correlation between the two types of attitudes (0.449) dissipating concerns with collinearity in the models [104]. Table 3 presents descriptive statistics regarding TPB constructs and personal norms (further descriptive analysis of the data can be found at Brune et al. [60]).

Table 3. Descriptive statistics for the difference (post-composite score-pre-composite score) of the constructs included in the analysis.

\begin{tabular}{cccccc}
\hline Variable & $\boldsymbol{n}$ & Mean & Std. Dev. & Min & Max \\
\hline Attitudes toward purchasing local food & 317 & 0.180 & 2.162 & -8 & 16 \\
Attitudes toward local food attributes & 321 & 0.318 & 1.429 & -4 & 12 \\
$\quad$ Subjective norms & 317 & 0.164 & 1.996 & -4 & 14 \\
$\quad \begin{array}{c}\text { Perceived behavioral control } \\
\text { Personal norms }\end{array}$ & 310 & 0.694 & 2.828 & -7 & 21 \\
$\quad 323$ & 0.189 & 1.664 & -5 & 11 \\
$\quad$ Behavioral intentions & & & & & \\
$\quad$ Purchase local food & 307 & 0.47557 & 1.665261 & -4 & 6 \\
Likelihood to increase budget to buy & 314 & 0.4363057 & 2.123372 & -6 & 8 \\
$\quad$ local food & 319 & 0.4043887 & 2.17969 & -8 & 8 \\
\hline Advocate for local food & & & &
\end{tabular}

Table 4 shows the results of the regression analysis comparing the impact of the behavioral antecedents on the three types of LFS engagement behavioral intentions. Results indicated that when controlling for demographic variables (age, sex, race, education, and income) positive changes in perceived behavioral control $(\beta=0.099, p=0.047)$ and personal norms $(\beta=0.381, p<0.001)$ positively influenced intentions to purchase local food $[F(11$, $\left.247)=4.31, R^{2}=0.161, p<0.001 ; \mathrm{VIF}=1.19\right]$. 
Table 4. Regression analysis of the effect of the change in TPB constructs and personal norms on changes in intentions to purchase local food, intentions to increase budget to buy local food, and intentions to advocate for local food.

\begin{tabular}{|c|c|c|c|c|c|c|c|c|c|}
\hline \multirow{2}{*}{ Variable } & \multicolumn{3}{|c|}{ Purchase Local Food } & \multicolumn{3}{|c|}{$\begin{array}{l}\text { Increase Budget to Buy } \\
\text { Local Food }\end{array}$} & \multicolumn{3}{|c|}{ Advocate for Local Food } \\
\hline & $B$ & & SE & $B$ & & SE & $B$ & & SE \\
\hline (Constant) & 3.478 & ** & 1.154 & 2.645 & $* * *$ & 0.691 & 1.380 & & 0.892 \\
\hline $\begin{array}{l}\text { Attitudes toward purchasing local } \\
\text { food }\end{array}$ & 0.017 & & 0.075 & 0.022 & & 0.060 & 0.045 & & 0.076 \\
\hline Attitudes toward local food attributes & -0.002 & & 0.105 & 0.015 & & 0.083 & -0.180 & & 0.105 \\
\hline Subjective norms & -0.032 & & 0.078 & 0.062 & & 0.062 & 0.242 & $* *$ & 0.083 \\
\hline Perceived behavioral control & 0.099 & * & 0.050 & 0.022 & & 0.039 & 0.028 & & 0.049 \\
\hline Personal norms & 0.381 & $* * *$ & 0.089 & 0.139 & * & 0.069 & 0.261 & ** & 0.088 \\
\hline Age & 0.001 & & 0.017 & -0.014 & & 0.013 & 0.016 & & 0.017 \\
\hline Sex & -0.568 & & 0.305 & 0.137 & & 0.241 & -0.141 & & 0.305 \\
\hline Race & 0.115 & & 0.365 & 0.609 & * & 0.286 & 0.300 & & 0.353 \\
\hline College education & 0.234 & & 0.295 & 0.020 & & 0.231 & 0.022 & & 0.295 \\
\hline Annual income above $\$ 75,000$ & 0.083 & & 0.280 & -0.140 & & 0.220 & -0.309 & & 0.281 \\
\hline Respective behavior pre-test score & -0.135 & $* * *$ & 0.036 & -0.164 & $* * *$ & 0.043 & -0.112 & $* *$ & 0.038 \\
\hline
\end{tabular}

Note: sex: 1 = male, $0=$ female or other; race: $1=$ non-white, $0=$ white $^{*} p<0.05 ;{ }^{* *} p<0.01{ }^{* * *} p<0.001$.

The regression analysis for intentions to increase monthly budget to purchase local food revealed that positive changes in personal norms $(\beta=0.139, p=0.046)$ is the only construct that influenced this intention $\left[F(11,242)=3.033, R^{2}=0.121, p=0.001, \mathrm{VIF}=1.15\right]$. Non-white respondents were also more likely to increase their monthly budget to purchase local food after an agritourism experience $(\beta=0.609, p=0.034)$. Results also showed that increases in subjective norms $(\beta=0.242, p=0.004)$ and personal norms $(\beta=0.261, p=0.003)$ positively impacted intentions to advocate for local food $\left[F(11,251)=3.577, R^{2}=0.136\right.$, $p<0.001, \mathrm{VIF}=1.17]$.

\section{Discussion}

When individuals make decisions about whether or not to purchase local foods and how much to spend, our results support previous research suggesting that internal attributes of perceived behavioral control and personal norms are motivating factors over social norms and attitudes $[25,73,93,105]$. Factors related to perceived behavioral control such as time availability, money, and accessibility are important predictors of privatesphere behaviors $[20,25,97]$. In addition, personal norms can reinforce these private-sphere behaviors [72]. In this case, personal norms was important in predicting intentions to purchase local foods, while also predicting intentions to increase personal budgets. These results suggest that initial decisions to purchase local foods may be based on convenience and access, and greater commitment stems from a sense of personal obligation. In other studies, the lack of predictive power of subjective norms on private behaviors has been attributed to the absence of observation of others performing the behavior [69]. In the agritourism setting, there was ample opportunity to observe others purchasing local food, adding further evidence to the possibility that subjective norms have limited ability to drive private-sphere behaviors, even when is possible to observe others perform the behavior. However, this raises broader questions about whether observing others perform a behavior can influence subjective norms. Future research should continue to investigate whether this finding holds in contexts other than local food purchasing.

In contrast, our results indicate that in the context of public-sphere behaviors (such as the intention to advocate for local food), personal norms are still important, but subjective norms rather than behavioral control are stronger motivating factors. The limited influence of behavioral control may reflect that citizens engage in public-sphere behaviors independently of perceived barriers when they feel helpless about an environmental issue and feel collective action may be the only solution [20]. In this case, however, results may also be 
related to how we measured the public-sphere behaviors (e.g., talking to family and friends about buying local food and talking to an elected representative about purchasing local food); given these are relatively accessible to everyone, the behavioral control may have a limited relationship. Instead, feelings of personal obligation and social pressure motivate these relatively simple, but arguably impactful actions in the public sphere. For instance, research on social movements suggests that conversations with close families and friends can support the social diffusion of ideas, such as support for sustainable behaviors [106]. Further, it is understandable that intentions to engage in behaviors that require social interaction are influenced by perceptions of social acceptability that would render them less socially risky [81]. Taken together, fostering social interactions at farms around supporting local food may promote social norms that increase the likelihood that people will talk about local foods with others, which in other topics such as climate change may be a critical step to promoting widespread adoption of sustainable behaviors $[107,108]$.

This study advances theory by demonstrating personal norms predict sustainable behaviors $[81,85-87,109,110]$ and that changes in personal norms are positively linked to changes in behavioral intentions. Though personal norms are considered relatively stable [111], agritourism experiences might demonstrate measurable changes by activating and maintaining awareness of what visitors already value in local farms [60]. Future studies could advance these findings by identifying the process of activation of personal norms occurring in agritourism experiences. For practitioners and policy makers, this study provides meaningful implications to foster the public's sustainable behaviors. Overall, our findings indicate that triggering a sense of moral obligation is a promising way of motivating the public to engage in both private and public-sphere sustainable behaviors. As activating personal norms or feelings of moral obligations depends on becoming aware of the negative consequences of not performing certain actions $[63,82]$, agritourism operators may increase the impact of experiences by illustrating the benefits that supporting local food brings to local farms and their surrounding economies. Educational signage and guided tours could help visitors connect local food to its social dimension (e.g., supporting family farms), and U-pick experiences can bring attention to sustainable agricultural practices employed in its production.

Beyond activating personal norms, agritourism might promote support for LFSs by building consumer confidence in where and how to buy local foods as well as leveraging the social aspects of the experience. For instance, agritourism operators might target behavioral control by advertising food delivery services, community-supported agriculture opportunities, or other ways that consumers might easily purchase local foods. Further, practitioners may explore opportunities to encourage farmers to lead advocacy efforts promoting LFS engagement behaviors that other visitors can participate in and/or witness (e.g., signing public petitions, having a 'look up your representative' station with letter templates and resources on how to get involved in group organizing). Similarly, encouraging visitors to invite others through referral incentive programs or other initiatives to promote social interaction around local foods may effectively encourage the spread of support for LFSs.

Changes in attitudes did not influence any of the behavioral intentions measured in our study. These results are consistent with previous evidence that solely modifying attitudes may not be enough to impact sustainable behavioral intentions $[73,93]$, which is worth stressing given the abundant efforts to encourage LFS engagement by stimulating attitudes change through informational campaigns and slogans $[30,112]$. Behaviors such as buying local food may require more effort to execute (e.g., travel distance to farmers market), thus, it is understandable that they do not solely depend on attitudinal factors. This provides more evidence to support the attitude-behavior gap $[76,93]$ and the importance of structural factors that can promote behavioral control such as access to local foods [58], or social learning in promoting behavior change [57]. 


\section{Limitations and Future Research}

The challenges inherent to our research design entailed measuring intentions rather than behaviors which is often the case when conducting survey-based research. As we measured intentions before and after an agritourism experience, measuring actual behaviors would have required tracking agritourists' behaviors before they engaged in agritourism experiences and after, which was not feasible. Ensuing efforts should attempt to complement survey-based inquiry with other observational methods. Yet, it may be too expensive to observe three behaviors in a large number of visitors [113]. Relatedly, we did not assess the durability of the impact of experiences on behaviors, an area of possible future research. As extended and recurring experiences can maintain intentions and develop habits [39], agritourism is well positioned to sustain behavioral intentions as visitors may return to farms several times a year to engage in activities focused on different crops, such as Upick strawberries (spring), blueberries (summer), and apples (fall). Future research could address how these repeat experiences may solidify interest in engaging in LFSs. As complementing TPB with personal norms enhances the analysis of private- and public-sphere behaviors in line with previous findings [85-87], it is worth exploring other theoretical approaches that account for moral considerations and might complement TPB such as environmental identity [114]. This study was geographically bound to North Carolina (USA). Thus, national, and international level research is necessary to confirm the impact of agritourism experiences on sustainable behaviors across different contexts. Given the necessity to increase global sustainability, especially focused on LFSs, future research should continue to identify ways to promote sustainable behaviors, in both private and public spheres, and pinpoint factors influencing such behaviors.

\section{Conclusions}

Through this study, we offer insight into the process of promoting sustainable behaviors and its implications for designing interventions. Our results stem from examining both the changes in the TPB behavioral antecedents and personal norms and the changes in behavioral intentions. Doing so allows us to capture these changes as a process rather than an outcome, which is consistent with understandings of how behaviors unfold [39]. Strategies to encourage LFS engagement should focus on activating moral considerations that can motivate action across both private and public behaviors. To promote collective action, strategies can target subjective norms specifically (e.g., encouraging social interaction around LFSs) while promoting private behaviors (e.g., buying local food) can be achieved by easing perceived barriers (e.g., familiarization with local food outlets). As agritourism experiences effectively modify the three behavioral antecedents-perceived behavioral control, subjective norms, and personal norms [60], we advocate for holistic experiences that provide opportunities for deeper engagement with an issue. In this case, agritourism can serve as the means to stimulate the visitors' senses to facilitate their social immersion in LFSs. As people learn through a variety of venues, the marketing and experiences associated with agritourism could be improved by considering it a learning intervention. This opens an opportunity for agritourism operators to leverage the impact of their offerings to generate or increase support for LFSs and loyalty to local food [49], and ultimately empower visitors to actively engage in their desired LFSs. Thus, expanding the access to agritourism experiences can be orchestrated with policies and programs to support citizens' intentions to adopt enduring sustainable behaviors and food choices.

Author Contributions: Conceptualization, S.B., W.K., K.S. and C.B.; methodology, S.B.; W.K., K.S. and C.B.; formal analysis, S.B.; writing-original draft preparation, S.B. and K.S.; writing-review and editing, W.K., K.S. and C.B.; project administration, K.S., W.K., C.B. and S.B.; funding acquisition, C.B., K.S. and W.K. All authors have read and agreed to the published version of the manuscript.

Funding: This research was funded by USDA-NIFA grant 2017-67023-26224 (2017-2022). 
Institutional Review Board Statement: The study was conducted according to the guidelines of the Declaration of Helsinki, and approved by the Institutional Review Board of North Carolina State University (protocol code 11810 and date of approval: 15 February 2017).

Informed Consent Statement: Informed consent was obtained from all subjects involved in the study.

Data Availability Statement: The data presented in this study are available on request from the corresponding author. The data are not publicly available due to funder not requiring public data sharing.

Acknowledgments: The authors wish to thank all the participating farms and volunteer graduate students that were key to collecting data for this project.

Conflicts of Interest: The authors declare no conflict of interest.

\section{Appendix A}

Table A1. Survey constructs and items and the source in the literature.

\begin{tabular}{|c|c|}
\hline Survey Constructs and Items & Source from the Literature \\
\hline \multicolumn{2}{|l|}{ Attitudes towards Local Foods Purchase } \\
\hline Is good for the environment & Denver and Jensen [95] \\
\hline Supports local economies & Onozaka et al. [94] \\
\hline Helps preserve agricultural landscapes & Onozaka et al. [94] \\
\hline Supports local farmers & Onozaka et al. [94] \\
\hline \multicolumn{2}{|l|}{ Attitudes towards Local Foods } \\
\hline Taste good & Denver and Jensen [95] \\
\hline Are fresh & Onozaka et al. [94] \\
\hline Are easy to find where I shop & Denver and Jensen [95] and Onozaka et al. [94] \\
\hline \multicolumn{2}{|l|}{ Subjective Norms } \\
\hline Would approve of me buying local foods & Hempel and Hamm [96]; Shin et al. [87] \\
\hline Think that I should buy local foods & Hempel and Hamm [96]; Shin et al. [87] \\
\hline Usually buy local foods & Hempel and Hamm [96]; Shin et al. [87] \\
\hline Would prefer me to buy local foods & Hempel and Hamm [96]; Shin et al. [87] \\
\hline \multicolumn{2}{|l|}{ Perceived Behavioral Control } \\
\hline Availability of local food in the community & Hempel and Hamm [96]; Onozaka et al. (2010) \\
\hline Possibility to buy local food in the near future & Shin et al. (2018) \\
\hline Affordability of local food & Hempel and Hamm [96]; Shin et al. [87] \\
\hline Time availability to buy local food & Shin et al. [87] \\
\hline Cooking skills to prepare local food & Hartmann, Dohle, and Siegrist [115] \\
\hline Knowledge of where to buy local food & Ajzen [78] \\
\hline Distance to purchase local food & Ajzen [78] \\
\hline \multicolumn{2}{|l|}{ Personal Norms } \\
\hline Get to know local farmers & Shin et al. [87] \\
\hline Support local farmers through the buying local food & Shin et al. [87] \\
\hline Support sustainable farming & Shin et al. [87] \\
\hline
\end{tabular}

\section{References}

1. WCED. The Report of the World Commission on Environment and Development: Our Common Future; Oxford University Press: Oxford, UK, 1987.

2. Gardner, G.T.; Stern, P.C. Environmental Problems and Human Behavior, 2nd ed.; Pearson Custom Publishing: Boston, MA, USA, 2002.

3. Haberl, H.; Fischer-Kowalski, M.; Krausmann, F.; Martinez-Alier, J.; Winiwarter, V. A socio-metabolic transition towards sustainability? Challenges for another Great Transformation. Sustain. Dev. 2011, 19, 1-14. [CrossRef]

4. Clark, M.; Tilman, D. Comparative analysis of environmental impacts of agricultural production systems, agricultural input efficiency, and food choice. Environ. Res. Lett. 2017, 12, 064016. [CrossRef]

5. Lyson, T.A.; Welsh, R. Agricultural Industrialization, Anticorporate Farming Laws, and Rural Community Welfare. Environ. Plan. A 2005, 37, 1479-1491. [CrossRef]

6. Lacroix, K. Comparing the relative mitigation potential of individual pro-environmental behaviors. J. Clean. Prod. 2018, 195, 1398-1407. [CrossRef]

7. Mbow, C.; Rosenzweig, C.; Barioni, L.G.; Benton, T.G.; Herrero, M.; Krishnapillai, M.; Liwenga, E.; Pradhan, P.; Rivera-Ferre, M.G.; Sapkota, T.; et al. Food security. In Climate Change and Land: An IPCC Special Report on Climate Change, Desertification, Land Degradation, Sustainable Land Management, Food Security, and Greenhouse Gas Fluxes in Terrestrial Ecosystems; Shukla, P.R., Skea, J., Buendia, E.C., Masson-Delmotte, V., Pörtner, H.-O., Roberts, D.C., Zhai, P., Slade, R., Connors, S., van Diemen, R., et al., Eds.; IPCC: Geneva, Switzerland, 2019; Available online: https:/ / www.ipcc.ch/srccl/ (accessed on 3 January 2022). 
8. Roser, M.; Ritchie, H. Hunger and Undernourishment. Available online: https://ourworldindata.org/hunger-andundernourishment (accessed on 31 October 2021).

9. United Nations. Food Security and Nutrition and Sustainable Agriculture. Available online: https://sustainabledevelopment.un. org/topics/foodagriculture (accessed on 31 October 2021).

10. Vermeulen, S.J.; Campbell, B.M.; Ingram, J.S.I. Climate Change and Food Systems. Annu. Rev. Environ. Resour. 2012, 37, 195-222. [CrossRef]

11. Tubiello, F.N.; Salvatore, M.; Ferrara, A.; Rossi, S.; Biancalani, R.; Federici, S.; Jacobs, H.; Flammini, A. Agriculture, Forestry and Other Land Use Emissions by Sources and Removals by Sinks; FAO: Rome, Italy, 2014; Volume 2.

12. Gleick, P.H. Water Use. Annu. Rev. Environ. Resour. 2003, 28, 275-314. [CrossRef]

13. FAO. World Agriculture: Towards 2015/2030: An FAO Study; FAO: Rome, Italy, 2003.

14. Mars, M.; Ball, A. Ways of Knowing, Sharing, and Translating Agricultural Knowledge and Perspectives: Alternative Epistemologies across Non-formal and Informal Settings. J. Agric. Educ. 2016, 57, 56-72. [CrossRef]

15. United Nations Environment Programme. Emissions Gap Report 2021: The Heat is On-A World of Climate Promises Not Yet Delivered; United Nations Environment Programme: Nairobi, Kenya, 2021.

16. La Trobe, H.L.; Acott, T.G. Localising the global food system. Int. J. Sustain. Dev. World Ecol. 2000, 7, 309-320. [CrossRef]

17. Schmitt, E.; Galli, F.; Menozzi, D.; Maye, D.; Touzard, J.-M.; Marescotti, A.; Six, J.; Brunori, G. Comparing the sustainability of local and global food products in Europe. J. Clean. Prod. 2017, 165, 346-359. [CrossRef]

18. Obach, B.K.; Tobin, K. Civic agriculture and community engagement. Agric. Hum. Values 2014, 31, 307-322. [CrossRef]

19. Seyfang, G. Ecological citizenship and sustainable consumption: Examining local organic food networks. J. Rural Stud. 2006, 22, 383-395. [CrossRef]

20. Ertz, M.; Karakas, F.; Sarigöllü, E. Exploring pro-environmental behaviors of consumers: An analysis of contextual factors, attitude, and behaviors. J. Bus. Res. 2016, 69, 3971-3980. [CrossRef]

21. Rotz, S.; Fraser, E.D.G. Resilience and the industrial food system: Analyzing the impacts of agricultural industrialization on food system vulnerability. J. Environ. Stud. Sci. 2015, 5, 459-473. [CrossRef]

22. Kloppenburg, J.; Hendrickson, J.; Stevenson, G.W. Coming in to the foodshed. Agric. Hum. Values 1996, 13, 33-42. [CrossRef]

23. Martinez, S.W.; Hand, M.; Da Pra, M.; Pollack, S.; Ralston, K.; Smith, T.; Vogel, S.; Clark, S.; Lohr, L.; Low, S.; et al. Local Food Systems: Concepts, Impacts, and Issues. USDA Econ. Res. Rep. 2010, 5, 80.

24. Steg, L.; Vlek, C. Encouraging pro-environmental behaviour: An integrative review and research agenda. J. Environ. Psychol. 2009, 29, 309-317. [CrossRef]

25. McGuirt, J.T.; Pitts, S.B.J.; Ward, R.; Crawford, T.W.; Keyserling, T.C.; Ammerman, A.S. Examining the Influence of Price and Accessibility on Willingness to Shop at Farmers' Markets Among Low-income Eastern North Carolina Women. J. Nutr. Educ. Behav. 2014, 46, 26-33. [CrossRef]

26. Stern, M.J.; Powell, R.B.; Hill, D. Environmental education program evaluation in the new millennium: What do we measure and what have we learned? Environ. Educ. Res. 2014, 20, 581-611. [CrossRef]

27. Barlagne, C.; Bazoche, P.; Thomas, A.; Ozier-Lafontaine, H.; Causeret, F.; Blazy, J.-M. Promoting local foods in small island states: The role of information policies. Food Policy 2015, 57, 62-72. [CrossRef]

28. Mugera, A.; Burton, M.; Downsborough, E. Consumer Preference and Willingness to Pay for a Local Label Attribute in Western Australian Fresh and Processed Food Products. J. Food Prod. Mark. 2016, 23, 452-472. [CrossRef]

29. Sahakian, M.; Wilhite, H. Making practice theory practicable: Towards more sustainable forms of consumption. J. Consum. Cult. 2013, 14, 25-44. [CrossRef]

30. Starr, A.; Card, A.; Benepe, C.; Auld, G.; Lamm, D.; Smith, K.; Wilken, K. Sustaining local agriculture Barriers and opportunities to direct marketing between farms and restaurants in Colorado. Agric. Hum. Values 2003, 20, 301-321. [CrossRef]

31. Jones, P.; Hillier, D.; Comfort, D. Shopping for tomorrow: Promoting sustainable consumption within food stores. Br. Food J. 2011, 113, 935-948. [CrossRef]

32. Jensen, K.O.D.; Denver, S.; Zanoli, R. Actual and potential development of consumer demand on the organic food market in Europe. NJAS Wagening. J. Life Sci. 2011, 58, 79-84. [CrossRef]

33. Nestle, M. Food Politics: How the Food Industry Influences Nutrition and Health; University of California Press: Berkeley, CA, USA, 2013.

34. Heslop, L.A. Literature Review of Canadian Consumer Attitudes and Perceptions; Carleton University Press: Ottawa, ON, Canada, 2007.

35. Jose, S.; Patrick, P.G.; Moseley, C. Experiential learning theory: The importance of outdoor classrooms in environmental education. Int. J. Sci. Educ. Part B Commun. Public Engagem. 2017, 7, 269-284. [CrossRef]

36. Carrier, S.; Thomson, M.M.; Tugurian, L.P.; Stevenson, K. Elementary Science Education in Classrooms and Outdoors: Stakeholder views, gender, ethnicity, and testing. Int. J. Sci. Educ. 2014, 36, 2195-2220. [CrossRef]

37. Stevenson, K.T.; Peterson, M.N.; Carrier, S.; Strnad, R.; Bondell, H.; Kirby-Hathaway, T.; Moore, S.E. Role of Significant Life Experiences in Building Environmental Knowledge and Behavior Among Middle School Students. J. Environ. Educ. 2014, 45, 163-177. [CrossRef]

38. Ting, D.H.; Cheng, C.F.C. Developing pro-environmental behaviour: Ecotourism fieldtrip and experiences. Int. J. Sustain. High. Educ. 2017, 18, 1212-1229. [CrossRef] 
39. Ardoin, N.M.; Wheaton, M.; Bowers, A.W.; Hunt, C.; Durham, W.H. Nature-based tourism's impact on environmental knowledge, attitudes, and behavior: A review and analysis of the literature and potential future research. J. Sustain. Tour. 2015, 23, 838-858. [CrossRef]

40. Ballantyne, R.; Packer, J. Using tourism free-choice learning experiences to promote environmentally sustainable behaviour: The role of post-visit 'action resources'. Environ. Educ. Res. 2011, 17, 201-215. [CrossRef]

41. Wearing, S.L.; McGehee, N.G. Volunteer Tourism. Tour. Manag. 2013, 38, 120-130. [CrossRef]

42. Schmitt, B. Experiential Marketing. J. Mark. Manag. 1999, 15, 53-67. [CrossRef]

43. Ajzen, I. Nature and Operation of Attitudes. Annu. Rev. Psychol. 2001, 52, 27-58. [CrossRef] [PubMed]

44. Ballantyne, R.; Packer, J. Introducing a fifth pedagogy: Experience-based strategies for facilitating learning in natural environments. Environ. Educ. Res. 2009, 15, 243-262. [CrossRef]

45. Stern, M.J.; Powell, R.B. What Leads to Better Visitor Outcomes in Live Interpretation? J. Interpret. Res. 2013, 18, 9-43. [CrossRef]

46. Arroyo, C.G.; Barbieri, C.; Rich, S.R. Defining agritourism: A comparative study of stakeholders' perceptions in Missouri and North Carolina. Tour. Manag. 2013, 37, 39-47. [CrossRef]

47. Dragulanescu, I.V.; Lanfranchi, M.; Giannetto, C. Agritourism farm in rural development framework and environmental sustainability. Qual. Access Success 2016, 17, 42-50.

48. Sotomayor, S.; Barbieri, C.; Stanis, S.W.; Aguilar, F.X.; Smith, J.W. Motivations for Recreating on Farmlands, Private Forests, and State or National Parks. Environ. Manag. 2014, 54, 138-150. [CrossRef]

49. Kline, C.; Barbieri, C.; LaPan, C. The Influence of Agritourism on Niche Meats Loyalty and Purchasing. J. Travel Res. 2016, 55, 643-658. [CrossRef]

50. Back, R.M.; Da Tasci, A.; Milman, A. Experiential consumption of a South African wine farm destination as an agritourism attraction. J. Vacat. Mark. 2019, 26, 57-72. [CrossRef]

51. Tew, C.; Barbieri, C. The perceived benefits of agritourism: The provider's perspective. Tour. Manag. 2012, 33, 215-224. [CrossRef]

52. Knollenberg, W.; Brune, S.; Harrison, J.; Savage, A.E. Identifying a community capital investment portfolio to sustain a tourism workforce. J. Sustain. Tour. 2021, 1-17. [CrossRef]

53. Thiermann, U.B.; Sheate, W.R. Motivating individuals for social transition: The 2-pathway model and experiential strategies for pro-environmental behaviour. Ecol. Econ. 2020, 174, 106668. [CrossRef]

54. Li, D.; Zhao, L.; Ma, S.; Shao, S.; Zhang, L. What influences an individual's pro-environmental behavior? A literature review. Resour. Conserv. Recycl. 2019, 146, 28-34. [CrossRef]

55. Robinson, R.; Smith, C. Psychosocial and Demographic Variables Associated with Consumer Intention to Purchase Sustainably Produced Foods as Defined by the Midwest Food Alliance. J. Nutr. Educ. Behav. 2002, 34, 316-325. [CrossRef]

56. Macovei, O.-I. Applying the Theory of Planned Behavior in Predicting Pro-environmental Behaviour: The Case of Energy Conservation. Acta Univ. Danubius. OEconomica 2015, 11, 15-32.

57. Heimlich, J.E.; Ardoin, N.M. Understanding behavior to understand behavior change: A literature review. Environ. Educ. Res. 2017, 14, 215-237. [CrossRef]

58. McGuirt, J.; Sitaker, M.; Pitts, S.J.; Ammerman, A.; Kolodinsky, J.; Seguin-Fowler, R. A Mixed-methods Examination of the Geospatial and Sociodemographic Context of a Direct-to-Consumer Food System Innovation. J. Agric. Food Syst. Community Dev. 2019, 9, 159-177. [CrossRef]

59. Abrahamse, W.; Steg, L.; Vlek, C.; Rothengatter, T. The effect of tailored information, goal setting, and tailored feedback on household energy use, energy-related behaviors, and behavioral antecedents. J. Environ. Psychol. 2007, 27, 265-276. [CrossRef]

60. Brune, S.; Knollenberg, W.; Stevenson, K.T.; Barbieri, C.; Schroeder-Moreno, M. The Influence of Agritourism Experiences on Consumer Behavior toward Local Food. J. Travel Res. 2021, 60, 1318-1332. [CrossRef]

61. Briscoe, M.D.; Givens, J.E.; Hazboun, S.O.; Krannich, R.S. At home, in public, and in between: Gender differences in public, private and transportation pro-environmental behaviors in the US Intermountain West. Environ. Sociol. 2019, 5, 374-392. [CrossRef]

62. Chen, H.; Chen, F.; Huang, X.; Long, R.; Li, W. Are individuals' environmental behavior always consistent?-An analysis based on spatial difference. Resour. Conserv. Recycl. 2017, 125, 25-36. [CrossRef]

63. Stern, P.C. Toward a Coherent Theory of Environmentally Significant Behavior. J. Soc. Issues 2000, 56, 407-424. [CrossRef]

64. Liu, X.; Zou, Y.; Wu, J. Factors Influencing Public-Sphere Pro-Environmental Behavior among Mongolian College Students: A Test of Value-Belief-Norm Theory. Sustainability 2018, 10, 1384. [CrossRef]

65. Poortinga, W.; Steg, L.; Vlek, C. Values, Environmental Concern, and Environmental Behavior. Environ. Behav. 2004, 36, 70-93. [CrossRef]

66. Kollmuss, A.; Agyeman, J. Mind the gap: Why do people behave environmentally and what are the barriers to pro-environmental behaviour. Environ. Educ. Res. 2002, 8, 239-260. [CrossRef]

67. Ajzen, I. Attitudes, Personality, and Behavior, 2nd ed.; Open University Press: Milton-Keynes, UK; McGraw-Hill International: Milton-Keynes, UK, 2005.

68. Huang, H. Media use, environmental beliefs, self-efficacy, and pro-environmental behavior. J. Bus. Res. 2016, 69, $2206-2212$. [CrossRef]

69. Ho, S.S.; Liao, Y.; Rosenthal, S. Applying the Theory of Planned Behavior and Media Dependency Theory: Predictors of Public Pro-environmental Behavioral Intentions in Singapore. Environ. Commun. 2015, 9, 77-99. [CrossRef] 
70. Ajzen, I. Consumer attitudes and behavior: The theory of planned behavior applied to food consumption decisions. Ital. Rev. Agric. Econ. 2016, 70, 121-138. [CrossRef]

71. Liu, A.; Ma, E.; Qu, H.; Ryan, B. Daily green behavior as an antecedent and a moderator for visitors' pro-environmental behaviors J. Sustain. Tour. 2020, 28, 1390-1408. [CrossRef]

72. Gkargkavouzi, A.; Halkos, G.; Matsiori, S. Environmental behavior in a private-sphere context: Integrating theories of planned behavior and value belief norm, self-identity and habit. Resour. Conserv. Recycl. 2019, 148, 145-156. [CrossRef]

73. Vermeir, I.; Verbeke, W. Sustainable Food Consumption: Exploring the Consumer "Attitude-Behavioral Intention" Gap. J. Agric. Environ. Ethics 2006, 19, 169-194. [CrossRef]

74. Barr, S. Factors influencing environmental attitudes and behaviors: A UK case study of household waste management. Environ. Behav. 2007, 39, 435-473. [CrossRef]

75. Mosler, H.-J.; Martens, T. Designing environmental campaigns by using agent-based simulations: Strategies for changing environmental attitudes. J. Environ. Manag. 2008, 88, 805-816. [CrossRef] [PubMed]

76. Juvan, E.; Dolnicar, S. The attitude-behaviour gap in sustainable tourism. Ann. Tour. Res. 2014, 48, 76-95. [CrossRef]

77. Cook, S.W.; Berrenberg, J.L. Approaches to Encouraging Conservation Behavior: A Review and Conceptual Framework. J. Soc. Issues 1981, 37, 73-107. [CrossRef]

78. Ajzen, I. The Theory of Planned Behavior. Organ. Behav. Hum. Decis. Process. 1991, 50, 179-211. [CrossRef]

79. Klöckner, C.A. A comprehensive model of the psychology of environmental behaviour-A meta-analysis. Glob. Environ. Chang. 2013, 23, 1028-1038. [CrossRef]

80. Wu, J.; Font, X.; Liu, J. Tourists' Pro-environmental Behaviors: Moral Obligation or Disengagement? J. Travel Res. 2021, 60, 735-748. [CrossRef]

81. Collado, S.; Staats, H.; Sancho, P. Normative Influences on Adolescents' Self-Reported Pro-Environmental Behaviors: The Role of Parents and Friends. Environ. Behav. 2019, 51, 288-314. [CrossRef]

82. Schwartz, S.H. Normative influences on altruism. In Advances in Experimental Social Psychology; Academic Press: Cambridge, MA, USA, 1977; Volume 10, pp. 221-279.

83. Stern, P.C.; Dietz, T.; Abel, T.D.; Guagnano, G.A.; Kalof, L. A Value-Belief-Norm Theory of support for social movements: The case of environmentalism. Res. Hum. Ecol. 1999, 6, 81-97. [CrossRef]

84. Whitley, C.T.; Takahashi, B.; Zwickle, A.; Besley, J.C.; Lertpratchya, A.P. Sustainability behaviors among college students: An application of the VBN theory. Environ. Educ. Res. 2018, 24, 245-262. [CrossRef]

85. Chen, M.-F.; Tung, P.-J. Developing an extended Theory of Planned Behavior model to predict consumers' intention to visit green hotels. Int. J. Hosp. Manag. 2014, 36, 221-230. [CrossRef]

86. Onel, N. Pro-environmental Purchasing Behavior of Consumers. Soc. Mark. Q. 2016, 23, 103-121. [CrossRef]

87. Shin, Y.H.; Im, J.; Jung, S.E.; Severt, K. The theory of planned behavior and the norm activation model approach to consumer behavior regarding organic menus. Int. J. Hosp. Manag. 2018, 69, 21-29. [CrossRef]

88. Zhang, X.; Geng, G.; Sun, P. Determinants and implications of citizens' environmental complaint in China: Integrating theory of planned behavior and norm activation mode. J. Clean. Prod. 2017, 166, 148-156. [CrossRef]

89. Mark, C.; Paul, N.; Russell, B. The theory of planned behavior and healthy eating. Health Psychol. 2002, 21, 194-201.

90. Bloom, J.D.; Hinrichs, C.C. Moving local food through conventional food system infrastructure: Value chain framework comparisons and insights. Renew. Agric. Food Syst. 2011, 26, 13-23. [CrossRef]

91. Schmidt, A.F.; Finan, C. Linear regression and the normality assumption. J. Clin. Epidemiol. 2018, 98, 146-151. [CrossRef] [PubMed]

92. Kline, R.B. Principles and Practice of Structural Equation Modeling, 3rd ed.; Guilford Press: New York, NY, USA, 2018.

93. Feldmann, C.; Hamm, U. Consumers' perceptions and preferences for local food: A review. Food Qual. Prefer. 2015, 40, 152-164. [CrossRef]

94. Onozaka, Y.; Nurse, G.; McFadden, D.T. Local food consumers: How motivations and perceptions translate to buying behavior. Choices 2010, 25, 7-12.

95. Denver, S.; Jensen, J.D. Consumer preferences for organically and locally produced apples. Food Qual. Prefer. 2014, 31, 129-134. [CrossRef]

96. Hempel, C.; Hamm, U. How important is local food to organic-minded consumers? Appetite 2016, 96, 309-318. [CrossRef]

97. Shi, R.; Hodges, A.W. Shopping at farmers' markets: Does ease of access really matter? Renew. Agric. Food Syst. 2016, 31, 441-451. [CrossRef]

98. Chen, W.; Scott, S. Shoppers' perceived embeddedness and its impact on purchasing behavior at an organic farmers' market. Appetite 2014, 83, 57-62. [CrossRef] [PubMed]

99. Xiao, C.; Hong, D. Gender differences in environmental behaviors in China. Popul. Environ. 2010, 32, 88-104. [CrossRef]

100. Nunnally, J.C. Psychometric Theory; Mc-Graw Hill: New York, NY, USA, 1967.

101. Hair, J.F.; Hult, G.T.M.; Ringle, C.M.; Sarstedt, M. A Primer on Partial Least Squares Structural Equation Modeling (PLS-SEM); Sage: Thousand Oaks, CA, USA, 2017.

102. Pell, G. Use and misuse of Likert scales. Med. Educ. 2005, 39, 970. [CrossRef]

103. Theobald, R.; Freeman, S. Is It the Intervention or the Students? Using Linear Regression to Control for Student Characteristics in Undergraduate STEM Education Research. CBE Life Sci. Educ. 2014, 13, 41-48. [CrossRef] 
104. Dormann, C.F.; Elith, J.; Bacher, S.; Buchmann, C.; Carl, G.; Carré, G.; Marquéz, J.R.G.; Gruber, B.; Lafourcade, B.; Leitão, P.J.; et al. Collinearity: A review of methods to deal with it and a simulation study evaluating their performance. Ecography 2013, 36, 27-46. [CrossRef]

105. Klöckner, C.A.; Ohms, S. The importance of personal norms for purchasing organic milk. Br. Food J. 2009, 111, $1173-1187$. [CrossRef]

106. Centola, D. How Behavior Spreads: The Science of Complex Contagions; Princeton University Press: Princeton, NJ, USA, 2018.

107. Hayhoe, K. When facts are not enough. Science 2018, 360, 943. [CrossRef] [PubMed]

108. Guilbeault, D.; Becker, J.; Centola, D. Social learning and partisan bias in the interpretation of climate trends. Proc. Natl. Acad. Sci. USA 2018, 115, 9714-9719. [CrossRef] [PubMed]

109. Han, H.; Yu, J.; Kim, H.-C.; Kim, W. Impact of social/personal norms and willingness to sacrifice on young vacationers' pro-environmental intentions for waste reduction and recycling. J. Sustain. Tour. 2018, 26, 2117-2133. [CrossRef]

110. Kim, M.J.; Hall, C.M.; Kim, D.-K. Predicting environmentally friendly eating out behavior by value-attitude-behavior theory: Does being vegetarian reduce food waste? J. Sustain. Tour. 2019, 28, 797-815. [CrossRef]

111. Conner, M.; Armitage, C. Extending the Theory of Planned Behavior: A Review and Avenues for Further Research. J. Appl. Soc. Psychol. 1998, 28, 1429-1464. [CrossRef]

112. Wang, X.; Qin, X.; Zhou, Y. A comparative study of relative roles and sequences of cognitive and affective attitudes on tourists' pro-environmental behavioral intention. J. Sustain. Tour. 2019, 28, 727-746. [CrossRef]

113. Juvan, E.; Dolnicar, S. Measuring environmentally sustainable tourist behaviour. Ann. Tour. Res. 2016, 59, 30-44. [CrossRef]

114. Clayton, S.; Czellar, S.; Nartova-Bochaver, S.; Skibins, J.; Salazar, G.; Tseng, Y.-C.; Irkhin, B.; Monge-Rodriguez, F. Cross-Cultural Validation of A Revised Environmental Identity Scale. Sustainability 2021, 13, 2387. [CrossRef]

115. Hartmann, C.; Dohle, S.; Siegrist, M. Importance of cooking skills for balanced food choices. Appetite 2013, 65, 125-131. [CrossRef] 